doi: 10.15503.onis2021.43.50

\title{
ZDOLNY, ALE GEJ. WPEYW INFORMACJI O KOMPETENCJI I ORIENTACJI SEKSUALNEJ NA PREFERENCJE PRZEŁOŻONEGO
}

\author{
Karolina Andrzejewska \\ Instytut Psychologii Uniwersytetu Wrocławskiego \\ ul. Dawida 1, 50-527 Wrocław, Polska \\ E-mail: k.andrzejewska9818@gmail.com \\ ORCID: https://orcid.org/0000-0003-1485-6670 \\ Szymon Błaszczyk \\ Instytut Psychologii Uniwersytetu Wrocławskiego \\ ul. Dawida 1, 50-527 Wrocław, Polska \\ E-mail: szymonblaszczyk01@gmail.com \\ ORCID: https://orcid.org/0000-0001-8509-9932 \\ Patrycja Demichowicz \\ Instytut Psychologii Uniwersytetu Wrocławskiego \\ ul. Dawida 1, 50-527 Wrocław, Polska \\ E-mail: patrycjademichowicz@gmail.com \\ ORCID: https://orcid.org/0000-0002-1427-8869 \\ Pamela Zuchowicz \\ Instytut Psychologii Uniwersytetu Wrocławskiego \\ ul. Dawida 1, 50-527 Wrocław, Polska \\ E-mail: pamela.zuchowicz@gmail.com \\ ORCID: https://orcid.org/0000-0001-8885-1851
}

\section{Abstrakt}

Cel. Celem badania było sprawdzenie czy informacja o orientacji seksualnej ma wpływ na preferencje przełożonego płci męskiej. Brano również pod uwagę zmienną kompetencji przełożonego oraz płeć osoby badanej.

Metody. W badaniu wzięło udział N=160 osób w przedziale wiekowym 18-35 lat, w tym 80 kobiet oraz 80 mężczyzn. Badanie wykonano w schemacie eksperymentalnym. W celu określenia preferencji przełożonego zastosowano autorski kwestionariusz.

Wyniki. Wyniki badania ujawniły istotny związek między płcią osoby badanej a preferencją przełożonego. Okazało się, że mężczyźni wykazywali preferencję przełożonego orientacji heteroseksualnej, natomiast u kobiet płeć przełożonego nie miała znaczenia. 
Wnioski. Mężczyźni homoseksualni doświadczają dyskryminacji ze względu na swoją orientację seksualną przez innych mężczyzn, nie zwracając uwagi na posiadane przez nich kompetencje. $Z$ kolei kobiety równo traktują mężczyzn bez względu na ich orientację seksualną.

Słowa kluczowe: homoseksualizm, geje, szef, mężczyźni homoseksualni, preferencja wyboru

Gifted but gay. Influence of information about sexual competence and orientation on the preferences of the superior

Abstract

Research goal. The main goal of the research was to verify if the information about sexual orientation has an impact on the preference of the potential superior. Candidate's competency and survey participant's gender were also taken into account as an variable.

Method. 160 people took part in the research in the age range 18-35, including 80 women and 80 men. Attitude towards presented man was measured by auctorial questionnaire, using survey method.

Results. Basing on the results of research on homosexual men in company, homophobic attitude towards them is presented mostly by heterosexual men. Women tend to stay neutral to their potential chief's sexual orientation.

Conclusion. Homosexual men are discriminated at work based on their orientation by over men, disregarding their competences. On the other hand, women treat men equally, regardless of their orientation.

Key words: homosexuality, gay, chief, homosexual men, boss preference

\section{WSTĘP TEORETYCZNY}

W dzisiejszych czasach osoby preferujące związki z osobą tej samej płci są szykanowane oraz obrażane. Zdarzają się również przypadki uszkodzenia zdrowia takiej osoby, a nawet zabójstwa. Negatywne odczucia oraz emocje dotyczące osób homoseksualnych, pojawiają się najczęściej z powodu braku wiedzy oraz istniejących stereotypów na ten temat. Osoby te są gorzej traktowane w życiu codziennym jak i zawodowym. Dodatkowo w miejscach pracy uważa się takie osoby za słabo radzące sobie ze stresem oraz sytuacjami stresowymi. Homoseksualiści kojarzeni są z ludźmi myślącymi ‘o niebieskich migdałach', skupiającymi się jedynie na swoich marzeniach. Michał Felisiak (2010) w swoim artykule poruszył temat podjęcia pracy przez osoby homoseksualne, z którego wynika, że część ludzi uważa, iż są stanowiska, których homoseksualiści nie powinni zajmować. Dodatkowo widoczne są różnice międzypłciowe: „Na deklaracje dotyczące zawodów dla homoseksualnych kobiet nie wpływa płeć respondentów, natomiast jeśli chodzi o ograniczenie dostępu do zawodów dla gejów, częściej postulują je mężczyźni niż kobiety" (Felisiak, 2010, s. 5-6). Do odpowiedzi, iż homoseksualiści nie powinni zajmować się niektórymi profesjami bardziej skłaniały się osoby młode (do 35 roku życia), niż starsze pokolenia. Różnice w podejściu do osób preferujących związki tej samej płci występują zarówno w kontekście płci, wieku jak i wielkości miasta, które osoba badana zamieszkuje. Dodatkowo słyszy 
się, iż osoby homoseksualne są mniej zaradne, kierują się uczuciami i wrażliwościa, przy czym heteroseksualne opisuje się jako dominujące, pewne siebie, ambitne bądź łatwo podejmujące decyzje.

Przyjrzyjmy się jak w świetle badań prezentują się postawy Polaków w stosunku do osób homoseksualnych. Jak wykazała Agencja Praw Podstawowych Unii Europejskiej (Eurosurveillance Editorial Team, 2013) 57\% badanych utożsamiających się z grupą LGBT oraz mieszkających w Polsce przyznało, że w czasie ostatniego roku doznało prześladowania z powodu orientacji seksualnej. M. Felisiak (2013) sugeruje, że w okresie od 2001 do 2013 roku liczba osób uważających, iż orientacja homoseksualna jest orientacją normalną lub zasługującą na to, by ją tolerować, wzrosła o $17 \%$. Jak pokazuje raport z badań sondażowych projektu „Równe traktowanie standardem dobrego rządzenia”, na największy dystans społeczny w Polsce narażeni są homoseksualni mężczyźni. Badanie przeprowadzone przez Centrum Badań nad Uprzedzeniami (Górska, Mikołajczak, 2014) zostało przeprowadzone w celu weryfikacji stopnia uprzedzeń w stosunku do osób posiadających orientację homoseksualną. Jak się okazało, przekonanie, że „osoby homoseksualne stanowią zagrożenie dla wszystkiego co dobre, moralne i normalne" podzieliło $29 \%$ respondentów. Z postawą mówiącą o tym, że „osoby homoseksualne zagrażają polskiej rodzinie” zgodziło się $35 \%$ uczestników badania. Z kolei obawę związaną z tym, że ,jeśli osoby homoseksualne zdobędą większe prawa, odbędzie się to ich kosztem", wyraziło 36\% badanych. Przy stwierdzeniach dotyczących zagadnienia tradycyjnej homofobii, również odnotowano podobne wyniki. Aż $22 \%$ biorących udział w eksperymencie Polaków uznało, iż "osób homoseksualnych powinno się unikać, kiedy tylko to możliwe". Dodatkowo $28 \%$ odpowiadających uznało homoseksualistów za niemoralnych, a $48 \%$ uważa, że osoby homoseksualne nie powinny mieć pozwolenia, aby pracować z dziećmi. Jak zauważono, istnieją 4 czynniki, które korelują z udzielanymi odpowiedziami. Należą do nich: wiek, zamieszkiwana miejscowość, wykształcenie oraz częstotliwość praktyk religijnych. Im osoba młodsza, tym bardziej pozytywne postawy przejawia wobec osób homoseksualnych. Mieszkańcy mniejszych miejscowości wykazują wyższy poziom uprzedzeń niż mieszkańcy większych miejscowości. Najwyższy poziom uprzedzeń występował wśród osób z wykształceniem gimnazjalnym i podstawowym, a najniższy u osób z wykształceniem wyższym. U osób religijnych, często praktykujących występują bardziej negatywne postawy wobec osób homoseksualnych, niż u osób praktykujących rzadziej.

Ciekawe wyniki zostały również otrzymane przy badaniu nowoczesnej homofobii. Ponad połowa badanych (53\%) uważa, iż „Osoby homoseksualne stały się zdecydowanie zbyt konfrontacyjne w swoich żądaniach o równouprawnienia". Zdecydowana mniejszość (34\%) uważa, że te osoby, które ujawniły swoją orientację, powinny być podziwiane w związku z tym za odwagę. Mniej niż połowa respondentów (43\%) jest zdania, że homoseksualiści wciąż nie mają pełnych praw i muszą o nie walczyć. Kobiety wykazują niższy poziom nowoczesnej homofobii niż mężczyźni. Jak pokazują badania, podobnie jak przy wynikach dotyczących tradycyjnej homofobii, występuje związek między wiekiem, wielkością zamieszkiwanej miejscowości oraz częstością praktyk religijnych a uprzedzeniami. Nie występuje natomiast związek między uprzedzeniami a wykształceniem.

Ogrody Nauk i Sztuk nR 2021 (11) 
Badania dowiodły również (Górska, Mikołajczak, 2015), że 25\% badanych wyraźnie sprzeciwiłoby się przyjęciu osoby o orientacji homoseksualnej w ich miejscu pracy, natomiast $26 \%$ nie chciałoby być sąsiadem homoseksualisty. Jak się również okazuje, bardziej pozytywny stosunek do przedstawicieli tej orientacji wykazywały kobiety. Jak pokazały wyniki badań CBOS (2010), 44\% osób uważa, że są zawody, których nie powinni wykonywać mężczyźni homoseksualni. Równocześnie przeważa przekonanie, że osoby heteroseksualne traktuje się lepiej, niż osoby homoseksualne (45\%). W roku 2009 oraz 2010 zespół prawników KPH otrzymał po około 60 zgłoszeń z pytaniami, z których część dotyczyła niezgodnego z prawem rozwiązania umowy, którego rzeczywistym powodem była orientacja seksualna pracownika.

Wnioski z badań przeprowadzonych na arenie międzynarodowej dotyczące funkcjonowania osób LGBT w pracy również nie są optymistyczne. Vickie M. Mays i Susan D. Cochran (2001) w swoich publikacjach na podstawie badań wyraźnie zauważaja, że osoby z grupy LGB doznają dwa razy częściej prześladowania, charakteryzującego się na przykład zwolnieniem z pracy. Patrycja Pogodzińska (2004) zauważa, że “dyskryminacja doświadczana przez osoby LGBT w zatrudnieniu to najczęściej dyskryminacja w zakresie rekrutacji i warunków pracy, w tym płacy, dostępu do awansu i szkoleń, molestowanie $\mathrm{w}$ miejscu pracy, pomijanie przy pewnych korzyściach przeznaczonych dla małżonków pracowników".

Celem prezentowanego badania było przyjrzenie się temu, czy i w jaki sposób społeczeństwo różnicuje postrzeganie osób w sferze zawodowej w zależności od ich orientacji seksualnej. Z uwagi na sugerowany $\mathrm{w}$ innych badaniach większy ładunek uprzedzeń wobec mężczyzn homoseksualnych, postanowiono skupić się właśnie na nich. Wyniki badań opublikowane przez CBOS (2010) pokazały, że to kobiety częściej niż mężczyźni wykazywały gotowość do pracy z osobą homoseksualną. Dodatkowo te same badania wykazały, że mężczyźni częściej postulują chęć ograniczenia dostępu do zawodu dla mężczyzn homoseksualnych Założono, że osoby badane będą mniej preferowały na stanowisku przełożonego mężczyznę homoseksualnego niż heteroseksualnego, niezależnie od informacji o posiadanych kompetencjach. Przypuszczano również, zgodnie z wynikami powyższych badań na ten temat, że kobiety będą wykazywać słabsze uprzedzenie do mężczyzny homoseksualnego w charakterze szefa w porównaniu do mężczyzn.

\section{Metodologia}

Postawiono następującą hipotezę H1: Mężczyzna homoseksualny będzie mniej preferowany na stanowisko przełożonego, niezależnie od posiadanych kompetencji.

W badaniu wyróżniliśmy następujące zmienne niezależne: płeć osoby badanej, kompetencja przedstawianego mężczyzny oraz orientacja seksualna przedstawianego mężczyzny. Wyszczególniliśmy również zmienna zależną, którą była preferencja wyboru na stanowisko przełożonego. Badani zostali podzieleni na 8 grup: (1) 20 kobiet i (2) 20 mężczyzn otrzymało profil mężczyzny heteroseksualnego kompetentnego, (3) 20 kobiet i (4) 20 mężczyzn otrzymało profil mężczyzny heteroseksualnego niekompetentnego, (5) 20 kobiet i (6) 20 mężczyzn otrzymało profil mężczyzny homoseksualnego kompetentnego, (7) 20 kobiet i (8) 20 mężczyzn otrzymało profil mężczyzny homoseksualnego niekompetentnego. 


\section{Procedura badania}

Badanie zostało przeprowadzone $\mathrm{w}$ formie online.

W celu zoperacjonalizowania zmiennych niezależnych zostały stworzone profile mężczyzn, które różniły się informacjami o kompetencji oraz orientacji seksualnej. Poniżej są przedstawione wybrane najważniejsze aspekty z profili mężczyzn.

- Profil mężczyzny homoseksualnego kompetentnego:

„Mam na imię Adam, mam 32 lata. Mam partnera, z którym uwielbiam spędzać czas. (...) Jestem absolwentem Uniwersytetu Warszawskiego. (...) Po ukończonych studiach zrobiłem studia podyplomowe MBA z specjalizacją Manager małej firmy. (...) Po ukończeniu studiów, zatrudnienie znalazłem jako manager w firmie korporacyjnej".

- Profil mężczyzny heteroseksualnego niekompetentnego:

„Mam na imię Adam, mam 32 lata. Mam żonę oraz dwójkę wspaniałych dzieci, z którymi uwielbiam spędzać czas. (...) Jestem absolwentem technikum gastronomicznego. (...) Po zakończonym technikum musiałem udać się za granicę, pracowałem jako pomoc kuchenna na zmywaku w Niemczech. (...) Po powrocie pracowałem jako sprzedawca w sklepie monopolowym".

W celu zoperacjonalizowania zmiennej zależnej stworzony został autorski kwestionariusz składający się z 9-ciu itemów (Andrzejewska, Błaszczyk, Demichowicz, Zuchowicz, 2019). Poniżej są przedstawione przykładowe twierdzenia z kwestionariusza: ${ }^{*}$ Chciałabym/ chciałbym mieć takiego szefa, *Ten mężczyzna jest godny zaufania, *Ten mężczyzna będzie sprawiedliwy wobec innych podwładnych.

Osoba badana wypowiadała się na skali interwałowej. Wysoki wynik na skali oznaczał, że osoba badana ma pozytywny stosunek do kandydata a niski równoznaczny był ze stosunkiem negatywnym.

\section{Osoby badane}

W badaniu wzięły udział $\mathrm{N}=160$ osób w przedziale wiekowym 18-35 lat. W badaniu wzięło udział 50\% (80 osób) kobiet heteroseksualnych oraz 50\% (80 osób) mężczyzn heteroseksualnych. Średnia wieku wynosiła 24,45 lat, a odchylenie standardowe 4,25 .

\section{REZULTATY BADANIA}

W celu przeanalizowania wyników badania, przeprowadzono analizę wariancji ANOVA. Uzyskano dwa istotne efekty główne oraz dwa efekty interakcji między zmiennymi.

Otrzymano istotny statystycznie efekt główny dla zmiennej kompetencja $[\mathrm{F}(1,152)$ $=89,34 ; \mathrm{p}<0,001]$. Można stwierdzić, że mężczyźni, których profile zawierały informacje o kompetencji $(\mathrm{M}=35,53 ; \mathrm{SE}=0,80)$ były preferowane w porównaniu do profili, które nie zawierały informacji o kompetencji $(\mathrm{M}=25,83$; $\mathrm{SE}=0,75)$.

Kolejnym efektem głównym, który okazał się istotny statystycznie, był efekt dla zmiennej orientacja seksualna przedstawianego profilu mężczyzny $[\mathrm{F}(1,152)=11,91$; $\mathrm{p}<0,001]$. Można stwierdzić, że orientacja seksualna mężczyzny ma wpływ na prefe- 
rencję przełożonego. Profile mężczyzn homoseksualnych zostały ocenione gorzej (M $=28,91 ; \mathrm{SE}=0,98)$, niż profile mężczyzn heteroseksualnych.

W wyniku interakcji obydwu zmiennych niezależnych (płeć osoby badanej oraz orientacja seksualna osoby przedstawionej na profilu) wykazano, że jest różnica istotna statystyczne. Kobiety stawiały równą ocenę niezależnie od orientacji, natomiast mężczyźni oceniali profil mężczyzny homoseksualnego bardziej negatywnie niż heteroseksualnego $[\mathrm{F}(1,152)=9,82 ; \mathrm{p}<0,002]$. Dzięki analizie porównań testu Bonferroniego dla testów post- hoc. Można stwierdzić, że są istotne różnice statystycznie wyników między grupami.

W przypadku grupy kobiet oceniających mężczyzn heteroseksualnych $(\mathrm{M}=31,33$; $\mathrm{SE}=1,29)$ oraz grupy mężczyzn oceniających mężczyznę homoseksualnego $(\mathrm{M}=$ 26,83; SE =1,44)- kobiety wyżej oceniły mężczyznę heteroseksualnego niż mężczyźni mężczyznę homoseksualnego $\mathrm{p}<0,02$.

W przypadku grupy kobiet oceniających mężczyznę homoseksualnego ( $M=31$; SE $=1,28)$ oraz grupy mężczyzn oceniających mężczyznę homoseksualnego $(M=26,83$; $\mathrm{SE}=1,44)$ - mężczyźni niżej ocenili mężczyznę homoseksualnego niż kobiety $\mathrm{p}<0,03$.

W przypadku grupy mężczyzn oceniających profil mężczyzny heteroseksualnego $(\mathrm{M}=33,58 ; \mathrm{SE}=1,15)$ oraz grupy mężczyzn oceniających profil mężczyzny homoseksualnego $(M=26,83$; $S E=1,44)$ - niżej ocenili profil mężczyzny homoseksualnego $\mathrm{p}<$ 0,01 .

Interakcja zmiennych niezależnych wygląda następująco: kompetencja osoby bodźcowej oraz orientacja osoby bodźcowej, wskazuje na wynik istotny statystycznie, niezależnie od tego jakiej orientacji jest przedstawiany mężczyzna, ponieważ w przypadku mężczyzny homoseksualnego i heteroseksualnego kompetentnego, był on oceniany wyżej niż mężczyzna niekompetentny $[\mathrm{F}(1,152)=5,77 ; \mathrm{p}<0,001]$.

Dzięki analizie porównań testu Bonferroniego dla testów post- hoc. można stwierdzić, że są istotne różnice statystycznie wyników między grupami:

- grupa oceniająca mężczyznę homoseksualnego niekompetentnego oceniła go niżej $(M=25,30 ; S E=1,13)$, niż grupa oceniająca mężczyznę heteroseksualnego kompetentnego $(\mathrm{M}=38,53 ; \mathrm{SE}=0,40) \cdot \mathrm{p}=0,0001$;

- grupa oceniająca mężczyznę homoseksualnego niekompetentnego oceniła go niżej $(M=25,30 ; S E=1,13)$, niż grupa oceniająca mężczyznę heteroseksualnego niekompetentnego $(\mathrm{M}=26,38 ; \mathrm{SE}=1,00) \cdot \mathrm{p}=0,0001$;

- grupa oceniająca mężczyznę homoseksualnego kompetentnego oceniła go niżej $(\mathrm{M}=32,53 ; \mathrm{SE}=1,40)$, niż grupa oceniająca mężczyznę heteroseksualnego kompetentnego $(\mathrm{M}=38,53 ; \mathrm{SE}=0,40) \cdot \mathrm{p}=0,0001$;

- grupa oceniająca mężczyznę homoseksualnego kompetentnego wyżej oceniła profil mężczyzny $(\mathrm{M}=32,53 ; \mathrm{SE}=1,40)$, niż grupa oceniająca mężczyznę heteroseksualnego niekompetentnego $(\mathrm{M}=26,38 ; \mathrm{SE}=1,00) \cdot \mathrm{p}=0,0002$;

- grupa oceniająca mężczyznę heteroseksualnego niekompetentnego niżej oceniła profil mężczyzny $(\mathrm{M}=26,38 ; \mathrm{SE}=1,00)$, niż grupa oceniająca mężczyznę heteroseksualnego kompetentnego $(M=38,53 ; \mathrm{SE}=0,40) \cdot \mathrm{p}=0,0003$.

Na podstawie analizy przeprowadzonych wyników można stwierdzić, że w grupie mężczyzn heteroseksualnych $\mathrm{w}$ dalszym ciagu istnieje zjawisko dyskryminacji wobec osób homoseksualnych. Kobiety podchodzą do mężczyzn homoseksualnych 
neutralnie. Można zauważyć, że tendencyjność dyskryminacji osób homoseksualnych $\mathrm{w}$ Polsce jest zdecydowanie malejąca, lecz jeszcze nie jest na takim poziomie, żeby mówić o tym, że w Polsce nie ma dyskryminacji wobec osób homoseksualnych.

\section{DYSKUSJA}

Głównym celem badań było sprawdzenie czy informacja o orientacji seksualnej ma wpływ na preferencje przełożonego płci męskiej. Profile kompetencyjne podczas doboru kadr kierowniczych oceniane są głównie pod względem wykształcenia ( $w$ wielu organizacjach, szczególnie państwowych, wymagane jest wyższe), a także niekaralności, oświadczenia o braku orzeczenia sądu o zakazie pełnienia danej funkcji czy spraw tak pozornie prozaicznych jak dobry stan zdrowia. Zatem profile stworzone zostały w taki sposób, by łatwo było określić kompetencje kandydata, które, jak się okazało, w rekrutacji na stanowisko szefa okazały się kluczowe, pomimo cech, przez których pryzmat oceniani są mężczyźni homoseksualni. A niewątpliwie są - dzieje się tak, ponieważ związki tej samej płci są wciąż szykanowane.

W badaniu zrealizowanym przez Edytę Charzyńską (2009), przy wykorzystaniu Inwentarza do Oceny Płci Psychologicznej (Kuczyńska, 1992), celem było ustalenie postrzegania cech osoby o danej płci (kobieta/mężczyzna) i orientacji (heteroseksualna, homoseksualna, biseksualna) przez nich samych oraz pozostałe grupy. Analizując wyniki możemy wyróżnić głównie interesujące nas spostrzeżenia: „typowy mężczyzna heteroseksualny w ocenie pozostałych grup: jest pewny siebie, dominujący i nie ma poczucia estetyki" oraz "typowy mężczyzna homoseksualny został przez wszystkie grupy badane scharakteryzowany jako: dbający o swój wygląd fizyczny, mający poczucie estetyki, eksperymentujący w życiu seksualnym, tolerancyjny, wrażliwy i uczuciowy". Precyzując, cechy jakimi określani są mężczyźni homoseksualni nie mają wiele wspólnego $\mathrm{z}$ cechami, jakimi według badań powinna charakteryzować się osoba na stanowisku kierowniczym.

Badanie zostało przeprowadzone na grupie kobiet i mężczyzn, lecz wyniki zdecydowanie wskazują na nasycony element homofobii u mężczyzn. Jednakże niezależnie od orientacji seksualnej potencjalnego kandydata z badania wynika, że mężczyzna kompetentny uzyskiwał wyższe oceny niż mężczyzna niekompetentny. Biorąc pod uwagę szereg badań innych autorów ten wynik jest zrozumiały, przede wszystkim dlatego, że stanowiska pracy posiadają wymagania dotyczące wnoszonego potencjału przez kandydata (Listwan, 2010). Według dotychczasowych badań wynika to z faktu, że płeć uważana jest za jeden z ważniejszych czynników przewidujących postawy wobec osób homoseksualnych (Herek, 2000). Wg Mary E. Kite i Bernard E. Whitleya (1996) heteroseksualni mężczyźni przejawiają więcej uprzedzeń wobec gejów i osób homoseksualnych w ogóle, niż heteroseksualne kobiety. Co ciekawe, przedstawiciele obojga płci nie różnią się pod względem postaw wobec lesbijek. Wynika to z różnic w treści kulturowego schematu kobiecości i męskości (Stefaniak, Bilewicz, Winiewski, 2015). Filarem męskości jest heteroseksualność, nie dotyczy to jednak kobiet (Kimmel, 1997). Heteroseksualni mężczyźni, stosując zachowania ukazujące uprzedzenia wobec osób homoseksualnych, dają świadectwo swojej normatywnej orientacji seksualnej, tym samym dopasowując się do swojej kulturowej roli płciowej (Berent, Falomir-Pichastor, Chipeaux, za: Herek, 2000).

Ogrody Nauk i Sztuk nR 2021 (11) 
W świetle otrzymanych wyników warto byłoby zorganizować badanie, które sprawdzi, w jaki sposób oceniani są kandydaci o różnych orientacjach i kompetencjach na niższe stanowiska, lub czy klaruje się różnica w preferencjach w przypadku rekrutacji do różnych branż (definiowanych jako typowo męskie lub kobiece - np. fryzjer, florysta, mechanik, kierowca). Edycja metryczki pod kątem orientacji osoby badanej mogłaby dać też nową zmienną - jak kobiety i mężczyźni homo- lub biseksualni postrzegają przedstawionych kandydatów. Ciekawe także mogłyby być badania dotyczące oceny kobiet homo- $i$ heteroseksualnych na stanowiskach kierowniczych, posiadających rozbieżne kompetencje, aby ustalić, czy może - $\mathrm{w}$ przeciwieństwie do mężczyzn - kobiety heteroseksualne posiadające wysokie kompetencje będą istotnie wyżej oceniane niż kobiety homoseksualne o takich samych kompetencjach. Owszem, dotychczasowe badania pokazują że to mężczyźni są bardziej preferowani na stanowiska kierownicze, lecz w literaturze coraz częściej pojawiają się wzmianki na temat przedsiębiorstw określanych jako „LGBTQ-friendly”(ang. przyjazne LGBTQ), przy czym wyszukiwanie frazy „,straight-friendly" przynosi 0 powiązanych artykułów.

\section{Bibliografia}

[1] Andrzejewska, K., Błaszczyk, S., Demichowicz, P., Zuchowicz, P. (2019). Kwestionariusz wyboru szefa. Nieopublikowany materiał do przeprowadzenia badania kwestionariuszowego. Wrocław: Instytut Psychologii UWr.

[2] CBOS (2010). Postawy wobec gejów i lesbijek, Warszaw: Fundacja Centrum Badania Opinii Społecznej.

[3] Charzyńska, E. (2009). Stereotypy atrybutów kobiecości/ męskości oraz hierarchii wartości osób o różnych orientacjach seksualnych. Przegląd terapeutyczny, 6-7. Pobrane z: http://www.ptt-terapia.pl/wp-content/uploads/2011/06/ Edyta_Charzynska.pdf.

[4] Eurosurveillance editorial team. (2013). The European Union Agency for Fundamental Rights publishes the European Union lesbian, gay, bisexual and transgender survey. Eurosurveillance, 18 (22), 20492.

[5] Felisiak, M. (2010). Postawy wobec gejów i lesbijek. Komunikat z badań (BS/95/2010). Warszawa: Fundacja Centrum Badania Opinii Społecznej.

[6] Felisiak, M. (2013). Równe traktowanie standardem dobrego rządzenia. Warszawa: Cebos.

[7] Górska, P., Mikołajczak, M. (2014). Postawy wobec osób homoseksualnych. Warszawa: Centrum Badań nad Uprzedzeniami.

[8] Górska, P., Mikołajczak, M. (2015). Tradycyjne i nowoczesne uprzedzenia wobec osób homoseksualnych w Polsce. W: A. Stefaniak, M. Bilewicz, M. Winiewski (red.), Uprzedzenia w Polsce (ss. 179-206). Warszawa: Liberi Libri.

[9] Herek, G. M. (2000). Sexual prejudice and gender: Do heterosexuals' attitude toward lesbians and gay men differ. Journal of Social Issues, 56, 251-266.

[10] Kimmel, M. S. (1997). Masculinity as homophobia: Fear, shame and silence in the construction of gender identity. W: M. M. Gergen \& S. N. Davis (red..), Toward a new psychology of gender (ss. 223-242). New York: Taylor \& Frances/ Routledge.

[11] Kite, M. E., Whitley, B. E. (1996). Sex differences in attitudes toward homosexual persons, behaviors, and civil rights a meta-analysis. Personality and Social Psychology Bulletin, 22, 336-353.

[12] Kuczyńska, A. (1992). Inwentarz do oceny Płci Psychologicznej. Warszawa: Pracownia Testów Psychologicznych PTP.

[13] Listwan T. (2010). Zarzadzanie kadrami. Warszawa: Wydawnictwo C.H. Beck.

[14] Mays V. M, Cochran S. D. (2001). Mental health correlates of perceived discrimination among lesbian, gay, and bisexual adults in the United States. Am. J. Publ. Health, 91, 1869-1876.

[15] Pogodzińska, P. (2004). Unijna zasada równego traktowania i swoboda przepływu pracowników w odniesieniu do sytuacji mniejszości seksualnych w zatrudnieniu. Problemy Wspótczesnego Prawa Międzynarodowego, Europejskiego i Porównawczego, 2, 73-114.

[16] Stefaniak, A., Bilewicz, M., Winiewski, M. (2015). Uprzedzenia w Polsce, Warszawa: Wydawnictwo Liberi Libri. 